\title{
Gephyrocharax torresi (Characiformes: Characidae: Stevardiinae), a new species from the río Cascajales basin, río Magdalena system, Colombia
}

\author{
James Anyelo Vanegas-Ríos ${ }^{1,3}$, María de las Mercedes Azpelicueta ${ }^{1}$, \\ Juan Marcos Mirande ${ }^{2}$ and María Dolly García Gonzales ${ }^{3}$
}

\begin{abstract}
A new species of Gephyrocharax is described from the río Cascajales basin, a tributary of the río La Colorada, río Magdalena system, Colombia. The new species is distinguished from its congeners, except G. melanocheir, by the absence of an adipose fin in most specimens and by the possession of a lateral branched pectoral-fin ray in males with a distal fan-shaped structure with minute bony hooks and a dark blotch or a few scattered dark brown chromatophores along its branches. The new species differs from G. melanocheir by the absence of an intense black pigmentation at the base of the anterior five dorsal-fin rays, the number of vertebrae (40-41 vs. 38-39), the frontals contacting each other anterior to the epiphyseal bar in adults ( $v s$. the absence of contact), the posterior margin of the mesethmoid straight in its central portion (vs. strongly concave at this point), the pouch scale of mature males reaching caudal-fin ray 11 or the area between caudal-fin rays 11 and 12 ( $v s$. reaching only to caudal-fin ray 10 or the area between caudal-fin rays 9 and $10)$, the number of minute terminal branches of the lateral branched pectoral-fin ray of mature males (60-88 vs. 28-54), a longer black lateral stripe along the body in males (reaching to the base of the caudal-fin rays $v s$. reaching the middle of the length of the caudal peduncle), and the snout length (28.3-31.8\% HL vs. 22.2-28.0\% HL). The diagnosis of Gephyrocharax is modified to include species with the adipose fin variably present.
\end{abstract}

Una nueva especie del género Gephyrocharax se describe para la cuenca del río Cascajales, tributario del río La Colorada, sistema del río Magdalena, Colombia. La nueva especie se distingue de sus congéneres, excepto G. melanocheir, por la ausencia de aleta adiposa en la mayoría de los individuos y por la presencia del radio ramificado lateral de la aleta pectoral con una estructura distal en forma de abanico, la cual tiene ganchos óseos diminutos y una mancha difusa oscura o unos pocos cromatóforos pardos oscuros a lo largo de sus ramificaciones. La nueva especie difiere de $G$. melanocheir por la ausencia de una intensa pigmentación negra sobre la base de los cinco radios anteriores de la aleta dorsal, el número de vértebras (40-41 vs. 38-39), los frontales contactando entre sí anteriormente a la barra epifisaria en adultos ( $v s$. la ausencia de contacto), el margen posterior del mesetmoides recto en su porción central ( $v s$. fuertemente cóncavo en este punto), la extensión dorsal de la escama-bolsillo de machos maduros alcanzando el radio caudal 11 o el área entre los radios caudales 11 y 12 ( $v s$. alcanzando el radio caudal $10 \mathrm{o}$ el área entre los radios caudales 9 y 10$)$, el número de ramificaciones terminales diminutas del radio ramificado lateral de la aleta pectoral (60-88vs. 28-54), la línea negra lateral sobre el cuerpo en machos más alargada (alcanzando la base de los radios de la aleta caudal vs. alcanzando la mitad de la longitud del pedúnculo caudal), y la longitud del hocico (28,3-31,8\% LC vs. 22,2-28,0\% LC). Modificamos la diagnosis de Gephyrocharax incluyendo especies con o sin aleta adiposa.

Key words: Glandular tissue, Neuromasts, Pouch scale, Stevardiini, Urogenital papillae.

${ }^{1}$ Consejo Nacional de Investigaciones Científicas y Técnicas (CONICET), División Zoología de Vertebrados, Facultad de Ciencias Naturales y Museo, Paseo del Bosque S/N B1900FWA, La Plata, Buenos Aires, Argentina. anyelovr@fcnym.unlp.edu.ar (JAVR), azpelicueta@gmail.com.ar (MMA)

${ }^{2}$ Consejo Nacional de Investigaciones Científicas y Técnicas (CONICET), Fundación Miguel Lillo, Miguel Lillo 251, San Miguel de Tucumán (4000), Tucumán, Argentina.mcmirande@gmail.com (JMM)

${ }^{3}$ Grupo de Investigación y Asesoría en Estadística, Facultad de Ciencias Básicas y Tecnologías, Bloque Nuevo, 2do Piso, Universidad del Quindío, Armenia, Colombia. mdgarcia@uniquindio.edu.co (MDGG) 


\section{Introduction}

Gephyrocharax Eigenmann is the most speciose genus of the tribe Stevardiini, containing twelve valid species (Weitzman \& Menezes, 1998; Weitzman, 2003; Menezes \& Weitzman, 2009). Species of Gephyrocharax are widely distributed through rivers and creeks of both cis- and transAndean basins in southern Central America and South America (Schultz, 1944; Weitzman, 2003).

Gephyrocharax caucanus Eigenmann, G. martae Dahl, and G. melanocheir Eigenmann (Eigenmann, 1912; Dahl, 1943) are the three currently recognized species of the genus in the ríos Cauca-Magdalena system (Schultz, 1944; Weitzman, 2003). Gephyrocharax caucanus occurs in the upper río Cauca, whereas G. martae and G. melanocheir are known from the río Magdalena basin; the latter species being widely distributed in that basin (Eigenmann \& Myers, 1929; Miles, 1947; Dahl, 1971), the Lago Maracaibo basin (Taphorn \& Lilyestrom, 1984) and some coastal Caribbean versant drainages (Bonilla-Rivero \& López-Rojas, 2001). Gephyrocharax melanocheir is distinguished from G. caucanus and G. martae mainly by the presence of a spot of intense black pigmentation at the base of the anterior five dorsal-fin rays in both sexes. Specimens from the río La Colorada basin in the río Magdalena system previously identified as G. melanocheir lack this conspicuous and intense pigmentation and represent a new species of Gephyrocharax described in the present paper.

\section{Material and Methods}

The material examined is deposited in the following collections: Asociación Ictiológica, La Plata (AI); American Museum of Natural History, New York (AMNH); Academy of Natural Sciences, Philadelphia (ANSP); California Academy of Sciences, San Francisco (CAS); private collection Carlos Ardila-Rodriguez, Barranquilla (CAR); Colección de Ictiología, Universidad de Antioquia, Medellín (CIUA); Ictiología, Colección Zoológica, Universidad del Tolima, Ibagué (CZUT-IC); Field Museum of Natural History, Chicago (FMNH); Instituto de Ciencias Naturales, Museo de Historia Natural, Universidad Nacional de Colombia, Bogotá (ICNMHN); Ictiología, Colección Zoológica, (INCIVA), Museo de Ciencias Naturales Federico Carlos Lehmann V., Cali (IMCN); Illinois Natural History Survey, Champaign (INHS); Museo de Biología, Universidad Central de Venezuela, Caracas (MBUCV); Museum of Comparative Zoology, Harvard University, Cambridge (MCZ); University of Florida, Florida Museum of Natural History, Gainesville (UF); Colección Ictiológica, Escuela de Biología, Universidad Industrial de Santander, Bucaramanga (UIST); National Museum of Natural History, Smithsonian Institution, Washington, D.C. (USNM); and Museum of Zoology, Lund University, Lund (ZMUL).

Measurements and counts follow Fink \& Weitzman (1974) and Menezes \& Weitzman (2009), with the addition of the distances from the dorsal fin to the pectoral fin (from the base of first unbranched dorsal-fin ray to the base of unbranched pectoral-fin ray), the dorsal fin to the adipose fin (from the base of the first unbranched dorsal-fin ray to the anterior most point of the base of the adipose fin), the pectoral fin to the pelvic fin (from the base of the unbranched pectoral-fin ray to the base of the unbranched pelvic-fin ray), the pelvic fin to the anal fin (from the base of the unbranched pelvic-fin ray to the base of anterior most externally visible anal-fin ray) and the postorbital head length (from the posterior border of the eye to the posterior most point of the bony opercle). The gill-gland length was measured between its anterior and posterior most margins in males. Measurements were taken point to point with a digital caliper under a stereomicroscope and are expressed as percentages of standard length (SL) or head length (HL) for subunits of the head.

Frequency of a particular character value is presented in parentheses with the holotype value indicated by an asterisk. The scales of the median dorsal row and the small scales situated just below the insertion of the anterior most dorsalfin ray are excluded from the counts of longitudinal scale rows between the dorsal fin and lateral line. Specimens were cleared and counterstained (c\&s) following Taylor \& van Dyke (1985). Total vertebral counts were determined in c\&s specimens and radiographs. These include the first preural centrum plus first ural centrum (PU1+U1) counted as one element and the four vertebrae of the Weberian apparatus.

Statistical analyses were performed using PAST 2.15 (Hammer et al., 2001) and SigmaPlot 10.0 for Windows (2006, Systat Software, Inc.) for morphometric variables. The Shapiro-Wilk test was used to test the normality of taken measurements. The non-parametric test of Spearman correlation was performed between the standard length and gill-gland length for the males of the new species. A significant $\mathrm{p}$-value $\leq 0.05$ was used to the bivariate statistical tests. The descriptions of sexually dimorphic characters are complemented by regression plots of caudal-peduncle length, pectoral-fin to pelvic-fin length, caudal-peduncle depth, and pelvic-fin length (all as function of SL).

\section{Results}

\section{Gephyrocharax torresi, new species Figs. 1-6}

Holotype. UIST 1767, 36.7 mm SL, male, Colombia, Santander, El Carmen, río Magdalena basin, río La Colorada basin, río Cascajales system, río Sucio basin, Caño Volador, 6³9'56.44”N 7334'47.36”W, approximately 338 m a.s.1., 17 Dec 2009, M. Torres.

Paratypes. All from Colombia, Santander: AI 293, 1 male c\&s, 34.7 mm SL, AI 294, 2, 34.0-36.0 mm SL, and UIST 1751, 19, 26.3-37.3 mm SL (1 c\&s, $36.0 \mathrm{~mm} \mathrm{SL}$ ), El Carmen, río Magdalena basin, río La Colorada basin, río Cascajales system, río Sucio under bridge to Vereda Islandia, 641'14.6”'N 73³5'15.10”'W, approximately 280 m a.s.1., 16 Dec 2009, M. Torres. AI 295, 2, 35.1-39.0 mm SL, and UIST 1766, 12, 32.0-42.0 mm SL, collected with holotype. 
Diagnosis. Gephyrocharax torresi is readily distinguished from its congeners (except G. melanocheir) by the absent or vestigial adipose fin ( $v s$. the presence of a well developed adipose fin), the form of lateral branched pectoral-fin ray of males which has a highly developed branching pattern that distally forms a fan-shaped structure with minute branches (vs. less extensive branching pattern not distally forming a fan-shaped structure with such minute branches), and the distal portion of this pectoral-fin ray in males with minute bony hooks (vs. hooks absent) and a dark blotch or a few scattered dark brown chromatophores along its branches ( $v s$. blotch or chromatophores absent). Gephyrocharax torresi differs from G. melanocheir by lacking intense black pigmentation at the base of the anterior five dorsal-fin rays (vs. the presence of such pigmentation), the number of vertebrae (40-41 vs. 38-39), the frontals contacting each other anterior to epiphyseal bar in adults ( $v s$. the absence of contact), the posterior margin of the mesethmoid straight in its central portion ( $v s$. strongly concave at this point), the pouch scale of mature males reaching caudal-fin ray 11 or the area between caudal-fin rays 11 and 12 (vs. reaching only to caudal fin ray 10 or the area between caudal-fin rays 9 and 10 ), the number of minute terminal branches of the lateral branched pectoral-fin ray of mature males (60-88 vs. 28-54), the longer midlateral black body stripe in males (reaching to the base of the caudal-fin rays $v s$. reaching to the middle of the caudal peduncle), and the snout length (28.3-31.8\% HL vs. $22.1-28.0 \% \mathrm{HL}$ ).

Description. Morphometric data in Table 1. Largest male $37.3 \mathrm{~mm}$ SL and largest female $42.0 \mathrm{~mm}$ SL. Body laterally compressed, with maximum depth at vertical through pelvicfin origin. Dorsal profile of head slightly convex from margin of upper lip to tip of supraoccipital spine. Dorsal profile of body straight from posterior portion of supraoccipital spine to dorsal-fin origin, slanting posteroventrally along dorsal-fin base, straight from posterior most dorsal-fin ray to caudal peduncle (Fig. 1). Ventral profile of body convex from tip of snout to pectoralfin origin, slightly convex between vertical through

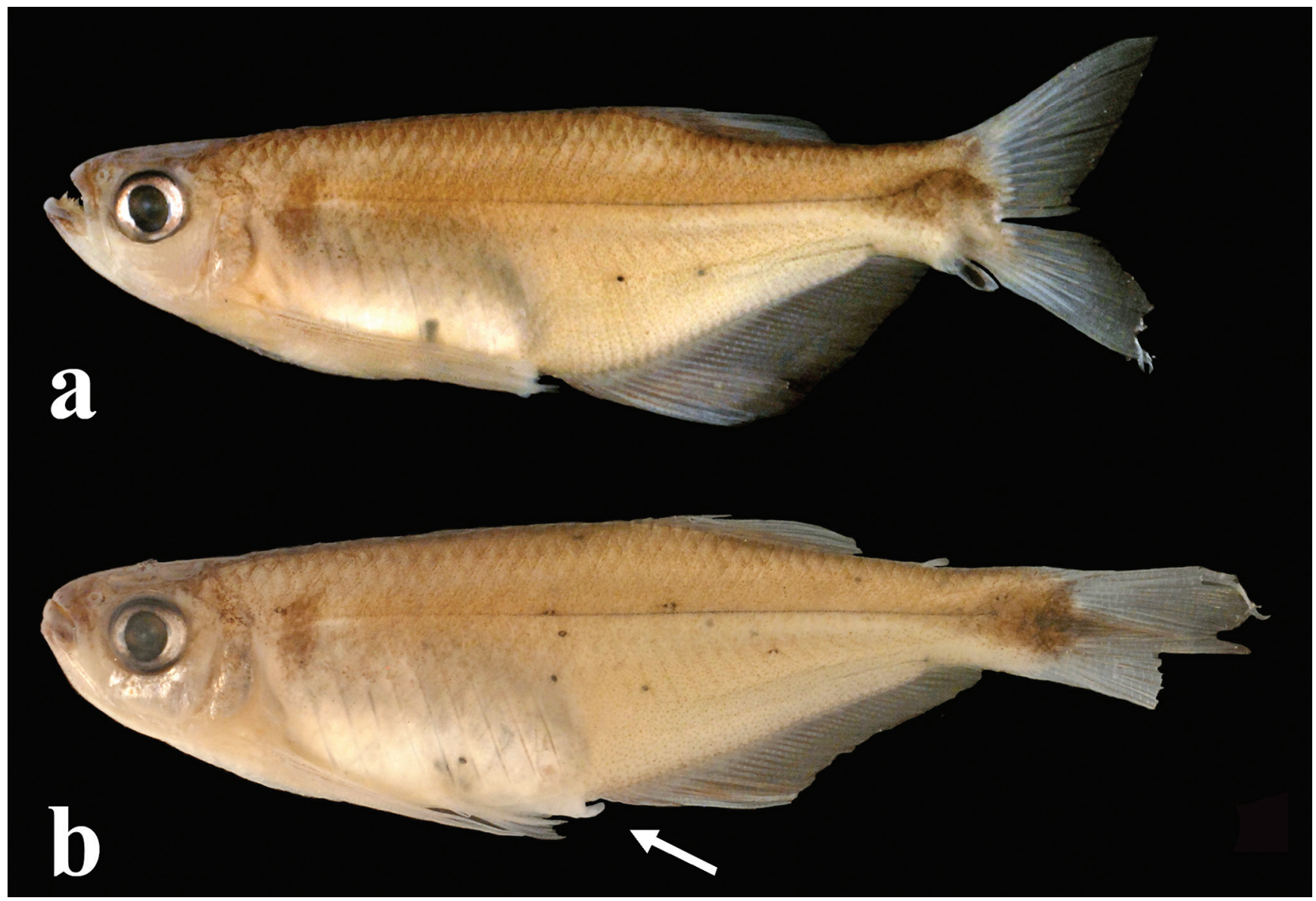

Fig. 1. Gephyrocharax torresi, (a) UIST 1767, holotype male, $36.7 \mathrm{~mm}$ SL, río Cascajales system, río La Colorada basin, río Magdalena system; (b) UIST 1766, paratype female, $42.0 \mathrm{~mm}$ SL, río Cascajales system, río La Colorada basin, río Magdalena system. Note externally developed urogenital papillae indicated by white arrow. 
Table 1. Morphometric data of holotype and 36 paratypes of Gephyrocharax torresi from río Cascajales system, río La Colorada basin, río Magdalena system. Counts are for 18 males and 19 females (for only three specimens of each sex for dorsalfin to adipose-fin length); $\mathrm{SD}=$ standard deviation. The values of the holotype are included in the range of males.

\begin{tabular}{|c|c|c|c|c|c|c|c|}
\hline \multirow{3}{*}{ Characters } & \multirow{3}{*}{ Holotype } & \multicolumn{6}{|c|}{ Paratypes } \\
\hline & & \multicolumn{3}{|c|}{ Males } & \multicolumn{3}{|c|}{ Females } \\
\hline & & Range & Mean & SD & Range & mean & SD \\
\hline Standard length $(\mathrm{mm})$ & 36.65 & $26.3-37.3$ & 33.21 & - & $27.3-42.0$ & 33.65 & - \\
\hline \multicolumn{8}{|c|}{ Percents of standard length } \\
\hline Depth at dorsal-fin origin & 31.87 & 27.3-31.9 & 29.53 & 1.41 & 27.4-32.0 & 29.28 & 1.05 \\
\hline Snout to dorsal-fin origin & 64.04 & $61.1-64.7$ & 62.83 & 1.17 & $60.3-64.9$ & 63.07 & 1.18 \\
\hline Snout to pectoral-fin origin & 27.86 & 27.2-28.9 & 28.09 & 0.44 & $25.6-29.0$ & 27.10 & 0.98 \\
\hline Snout to pelvic-fin origin & 45.24 & $44.3-48.1$ & 45.96 & 0.92 & $44.2-48.9$ & 46.52 & 1.04 \\
\hline Snout to anal-fin origin & 60.16 & $56.9-60.6$ & 59.03 & 1.11 & $57.7-61.9$ & 59.79 & 1.19 \\
\hline Dorsal-fin to pectoral-fin length & 47.45 & $43.8-47.5$ & 45.78 & 1.27 & 44.3-48.9 & 46.30 & 1.27 \\
\hline Dorsal-fin to adipose-fin length & - & $26.0-27.7$ & 26.97 & 0.87 & 26.1-27.9 & 27.25 & 1.01 \\
\hline Dorsal-fin to hypurals complex length & 37.41 & $36.6-41.3$ & 38.91 & 1.19 & $36.9-40.8$ & 39.03 & 1.07 \\
\hline Eye to dorsal-fin origin & 51.32 & $48.8-52.2$ & 50.71 & 1.12 & $48.8-53.1$ & 50.90 & 1.12 \\
\hline Pectoral-fin to pelvic-fin length & 17.84 & $17.2-20.8$ & 18.74 & 1.10 & $19.1-22.2$ & 20.49 & 0.78 \\
\hline Pelvic-fin to anal-fin length & 15.85 & $13.4-16.6$ & 14.80 & 1.01 & $12.9-16.9$ & 15.18 & 1.00 \\
\hline Dorsal-fin length & 22.35 & $19.7-24.1$ & 21.45 & 1.38 & 18.6-21.9 & 20.36 & 0.95 \\
\hline Dorsal-fin base length & 9.88 & $9.0-11.5$ & 10.21 & 0.69 & $8.6-10.7$ & 9.75 & 0.61 \\
\hline Pectoral-fin length & 30.53 & $27.6-33.5$ & 30.10 & 1.52 & 26.4-30.4 & 28.22 & 1.19 \\
\hline Pelvic-fin length & 17.63 & $14.1-18.3$ & 16.36 & 1.48 & $13.1-15.8$ & 14.38 & 0.69 \\
\hline Anal-fin length & 21.94 & 20.4-23.9 & 21.68 & 0.93 & $18.6-22.2$ & 20.40 & 0.92 \\
\hline Anal-fin base length & 38.04 & $33.8-38.0$ & 36.08 & 1.12 & $34.2-37.1$ & 35.45 & 0.83 \\
\hline Caudal-peduncle depth & 13.37 & $10.6-13.7$ & 12.21 & 0.96 & $10.0-10.8$ & 10.32 & 0.26 \\
\hline Caudal-peduncle length & 9.71 & $9.4-12.1$ & 10.79 & 0.71 & $8.6-10.9$ & 9.65 & 0.50 \\
\hline Bony head length & 24.80 & $23.6-25.9$ & 24.43 & 0.58 & $22.7-25.2$ & 23.73 & 0.63 \\
\hline \multicolumn{8}{|c|}{ Percents of head length } \\
\hline Snout length & 29.59 & $28.5-31.8$ & 29.95 & 0.98 & 28.3-31.8 & 30.36 & 1.00 \\
\hline Horizontal eye length & 34.65 & $31.5-36.8$ & 34.17 & 1.43 & $30.5-37.3$ & 34.43 & 1.61 \\
\hline Postorbital head length & 40.15 & $38.1-41.9$ & 40.11 & 1.06 & $35.3-39.9$ & 38.84 & 1.05 \\
\hline Least interorbital width & 38.83 & $36.0-39.1$ & 37.39 & 0.94 & $35.4-38.8$ & 37.49 & 0.99 \\
\hline Upper jaw length & 46.20 & $40.8-47.6$ & 44.04 & 1.70 & $41.8-48.8$ & 45.27 & 1.80 \\
\hline
\end{tabular}

pectoral-fin and pelvic-fin origins, slanting posterodorsally and straight from this point to caudal peduncle. Anterior fontanel absent or reduced to narrow opening anterior to epiphyseal bar. Anterior nostril rounded and separated by skin fold from larger posterior nostril. Groove with at least three rows of neuromasts extending from point half way between posterior pore of nasal bone and nostrils to posterior portion of frontals. Smaller groove with few neuromasts between nostrils and nasal bones.

Dorsal-fin rays ii, $7 *$ (14) or 8 (23); proximal pterygiophores 9. Dorsal-fin origin located at vertical through base of analfin rays 5 to 8 . Adipose fin reduced in size (6) or absent* (31). When present, adipose fin located at vertical through base of four or five posterior most anal-fin rays. Anal fin with $4 *(30)$ or 5 (7) unbranched rays followed by 26 (1), 27 (4), 28 (9), 29* (14), or 30 (9) branched rays. Anal-fin proximal pterygiophores 29-30. Anal-fin origin closer to origin of hypural joint than to snout tip. Pectoral-fin rays i,8 (5), 9 (25), 10* (6), or 11 (1). Pectoral fin long, extending posteriorly to one-third or more of vertical through pelvic-fin origin. Pelvic-fin rays i,6* (37). Pelvic-fin origin located at vertical through lateral-line scales 9 to 11 and slightly anterior to midpoint of body. Caudal fin forked with 10/9 principal rays in all specimens.

Mouth superior, lower jaw projecting slightly anterior to tip of upper jaw. Premaxilla with two rows of teeth. Outer row

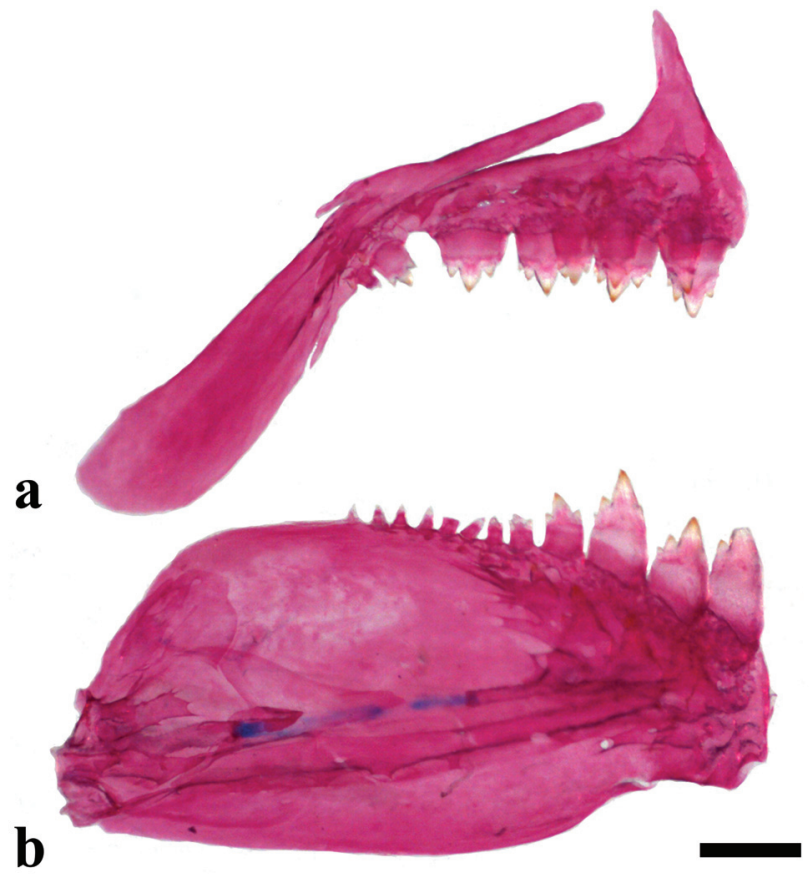

Fig. 2. Lateral view of jaws and dentition of Gephyrocharax torresi, UIST 1751, paratype female, $36.7 \mathrm{~mm} \mathrm{SL}$, right side. (a) Premaxilla and maxilla. (b) dentary, anguloarticular, and retroarticular bones. 
with $3 *(30)$ or 4 (7) usually tricuspidate, rarely bicuspidate teeth. Inner row with $4 *(33)$ or 5 (4) teeth; symphyseal tooth tetracuspidate and remaining teeth pentacuspidate. Maxilla with 1 (23), 2 (13), or $3 *$ (1) teeth; all teeth tricuspidate or tetracuspidate (Fig. 2a). Maxilla long, reaching posteriorly to vertical through anterior one-third of eye. Dentary with 9 (1), $10(1), 11(7), 12(8), 13^{*}(7)$, or 14 (2) teeth: three anterior most teeth large and pentacuspidate and followed by one median sized, usually tricuspidate tooth and 5 (1), $6(1), 7(7), 8(8), 9^{*}$ (7), or 10 (2), tricuspidate or conical smaller teeth (Fig. 2b).

Scales cycloid, with several radii along posterior field. Lateral line complete. Pored scales 40 (1), 41 (10), 42 (15), 43* (10), or 44 (1); one specimen with lateral line interrupted, with several scales lacking pores. Terminal lateral-line tube absent. Predorsal scales 18* (9), 19 (20), 20 (5), or 21 (3). Scale rows between dorsal fin and lateral line 5 (3) or $6 *$ (34). Scale rows between lateral line and anal fin 4 (13) or $5^{*}(24)$. Scale rows between lateral line and pelvic fin $4^{*}(1)$ or $5(26)$. Circumpeduncular scales $14(16), 15^{*}(18)$, or $16(3)$. One row of $14(3), 15(3), 16(8), 17^{*}(5), 18(3), 19(3), 20(8), 21$ (1), or 22 (3) scales forming sheath along anal-fin base. Total number of vertebrae 40-41 (in two c\&s specimens). Gill-rakers on dorsal limb of first branchial arch 5 (1) or 6* (21); ventral limb with 11 (1), $12(18)$, or $13 *(3)$.

Color in alcohol. Ground color pale yellowish, darker along mid-dorsal line and slightly lighter ventrally. Minute brown chromatophores completely covering body. Black lateral stripe extending from posterior region of opercle to central or posterior portion of caudal peduncle. Dark brown chromatophores present along myosepta between lateral line and upper portion of anal fin. Humeral spot vertically elongate. Large dark brown spot on caudal peduncle. Dorsal fin dusky with dark brown chromatophores concentrated on rays and membranes. Anal fin dusky with dark brown and black chromatophores located on membranes: chromatophores on anterior and distal portions of fin usually more densely concentrated in males. Caudal fin

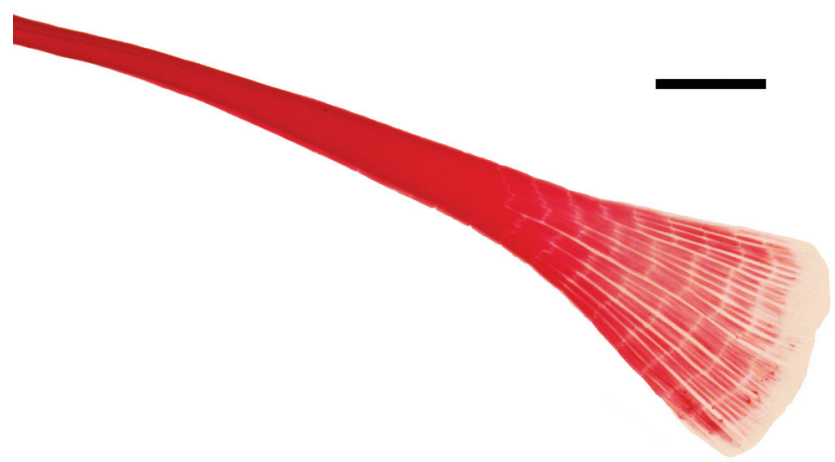

Fig. 3. Lateral view of lateral branched pectoral-fin ray of Gephyrocharax torresi, AI 293, paratype male, $34.7 \mathrm{~mm} \mathrm{SL}$, left side. Scale bar $=1 \mathrm{~mm}$. hyaline with few scattered, dark brown or black chromatophores on rays and membranes. Pectoral and pelvic fins hyaline with scattered black chromatophores on rays. Head darker dorsally. Few dark brown chromatophores distributed on opercle and infraorbitals. Premaxilla, anterior portions of maxilla, dentary, and lips with dark brown chromatophores. Snout heavily pigmented by dark brown chromatophores. Variations in color pattern between males and females discussed under sexual dimorphism.

Sexual dimorphism. Male, but not female, specimens of Gephyrocharax torresi with bony hooks on rays of anal, caudal, pectoral and pelvic fins. Caudal fin with short, slender anterodorsally oriented hooks on unbranched
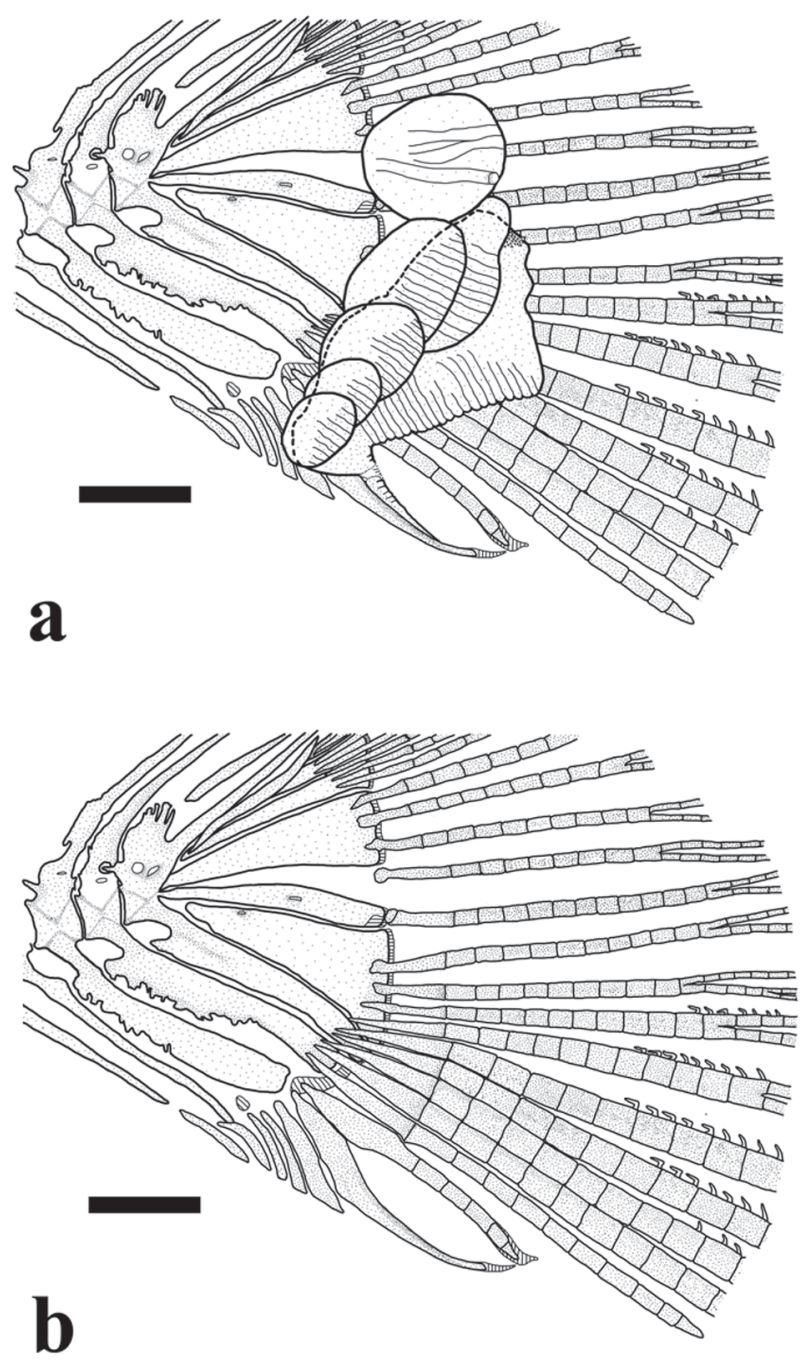

Fig. 4. Lateral view of caudal fin of Gephyrocharax torresi, AI 293, paratype male, $34.7 \mathrm{~mm}$ SL, left side, depicting: (a) pouch scale and associated caudal-fin squamation in ventral lobe; (b) caudal fin lower lobe rays and claw (scales removed). Scale bar $=1 \mathrm{~mm}$. 
portions and dorsal branches of rays 14-18 (Fig. 4). All rays of pelvic fin with slender, anterolaterally oriented hooks along nearly entire length of each ray; usually one pair per segment. Pectoral fin with few scattered, minute bony hooks on distal portion of lateral branched ray. Anal fin with slender, anterodorsally placed hooks with broad bases, one pair per segment. From three to 12 pairs of hooks located on posterior most unbranched and up to first seven branched rays. Posterior most unbranched and first 18 branched anal-fin rays gradually decreasing in length in males; females with posterior most unbranched and anterior 1-3 branched anal-rays longer than remaining rays. Mature females with large, usually posteroventrally oriented, conical urogenital papilla (Fig. 1b).

Caudal spot of males only reaching base of caudal-fin rays but extending over middle caudal-fin rays in females. Males with caudal spot chromatophores bounding pouch scale dorsally but leaving clear area in lower portion of caudal peduncle, whereas females with that spot extending completely onto caudal peduncle. Lateral stripe of males bounding caudal spot dorsally versus ending on anterior or middle portions of caudal spot in females. Males differ from females in presence of dark blotch or few scattered dark brown chromatophores on distal portion of lateral branched pectoral-fin ray but rarely on contiguous proximal ray. Distal portion of lateral branched pectoral-fin ray modified in both sexes; branching more complex in males. In males, posterior half of external branched pectoral-fin ray thicker, splitting into two equal branches; each branch dividing into three smaller branches and each one of these six branches splitting further to form distal structure with 60 (1), 61 (1), 62 (2), 64 (1), 70 (3), 72* (1), 78 (1), or 88 (1) minute branches (Fig. 3). In females, lateral branched pectoral-fin ray splits into two principal branches; outer branch divides into four short branches and inner into three short branches. Each of these seven slender branches usually splits one more time.

Males with modified scale forming pouch on lower lobe of caudal fin and with ventral procurrent rays 2 and 3 in form of a claw-shaped structure immediately ventral to ray 9 of lower lobe of caudal fin (lower caudal fulcra free and forming peculiar spur described by Eigenmann, 1912). Tissue of glandular appearance located on caudal-fin rays and medially to pouch scale. Second ventral procurrent ray somewhat longer than third ray. Claw-shaped structure incompletely ossified distally; claw reaching half length of first ventral procurrent ray (Fig. 4). Hypertrophied pouch scale usually with 26 or 30 radii; first 22 radii often located between caudal-fin rays 17 or 18 and second ventral procurrent ray, remaining radii distributed from that point to lateral border of third ventral procurrent ray. Posteroventral portion of pouch scale fused to third ventral procurrent ray. Dorsal surface of pouch scale attached via soft tissue to caudal-fin rays 9 to 15 . Posterior margin of pouch scale located between caudal-fin ray 15 and third ventral procurrent ray. Four or five scales in vertical series just below posterior most lateral-line scale and on posterior portion of pouch scale. Median scale with undulated margin located between these scales and pouch scale. Series of minute spinous processes forming patch on dorsal portion of pouch scale. Females with large scale with 20 (1), 21 (3), 22 (2), 24 (2), 26 (2), 27 (1), 28 (2), or 29 (3) radii on lower caudal-fin lobe.

Mature males with long gill gland (two juvenile males with poorly developed gill gland excluded from following counts). Gill gland formed by modified ventral 11 (1), 12 (1), 14 (1), 20 (2), 21 (3), 22* (3), 23 (3), or 24 (2) gill filaments of ventral limb of first functional branchial arch. Total gill filaments on ventral limb 23 (2), 24 (1), 25 (3), 26 (2), 27 (2), 28 (2), 29 (2), or $30 *(2), n=16$. Gill-gland length $6.0-10.3 \% \mathrm{SL}$ $($ mean $=8.6 \% \mathrm{SL}), 8.7 \% \mathrm{SL} *$. Standard and gill-gland lengths positively correlated (normality test, respectively: $\mathrm{W}=0.89$, $\mathrm{p}=0.055, \mathrm{n}=16, \mathrm{~W}=0.88, \mathrm{p}=0.038$; Spearman test: $\mathrm{r}=0.83$, $\mathrm{p}<0.001)$. Caudal-peduncle depth, pectoral-fin to pelvic-fin length, pelvic-fin length, and caudal-peduncle length sexually dimorphic as function of SL and with differences more pronounced in larger specimens (Fig. 5). Males with higher values than females in all these measurements except pectoral-fin to pelvic-fin length.

Distribution. Gephyrocharax torresi is known from two localities of the río Sucio basin, río Cascajales system, río La Colorada basin, río Magdalena basin, Colombia (Fig. 6).

Etymology. The species name torresi is treated as a patronym in gratitude and recognition of Mauricio Torres who collected the material on which the description is based.

\section{Discussion}

Gephyrocharax was described by Eigenmann (1912) based on the following characters: "Premaxillary teeth in two distinct series, five teeth in the inner series. Second suborbital covering the entire cheek. Caudal without glandular scales, the lower caudal fulcra free and forming a peculiar spur in the male. Adipose fin present. Origin of dorsal nearer to caudal than the eye, considerably behind the vertical from origin of anal, pectorals large, overlapping the ventrals". Subsequently, Myers (in Eigenmann \& Myers, 1929: 477) revised Gephyrocharax and added the character "frontal fontanel present or absent" as part of his diagnosis of the genus. Schultz (1944) and Dahl \& Medem (1964) apparently followed Myers's diagnosis of Gephyrocharax.

All the previously described species of Gephyrocharax share the presence of a well-developed adipose fin, a feature widespread among the Characidae. The adipose fin is lacking or much reduced in G. torresi and as such the occurrence of an adipose fin is intragenerically variable. Mirande (2010: 548) proposed two unambiguous losses of the adipose fin within the Characidae: in the Gymnocharacinae and in Phenagoniates macrolepis (Meek \& Hildebrand), neither of which is closely related to the Stevardiinae. 

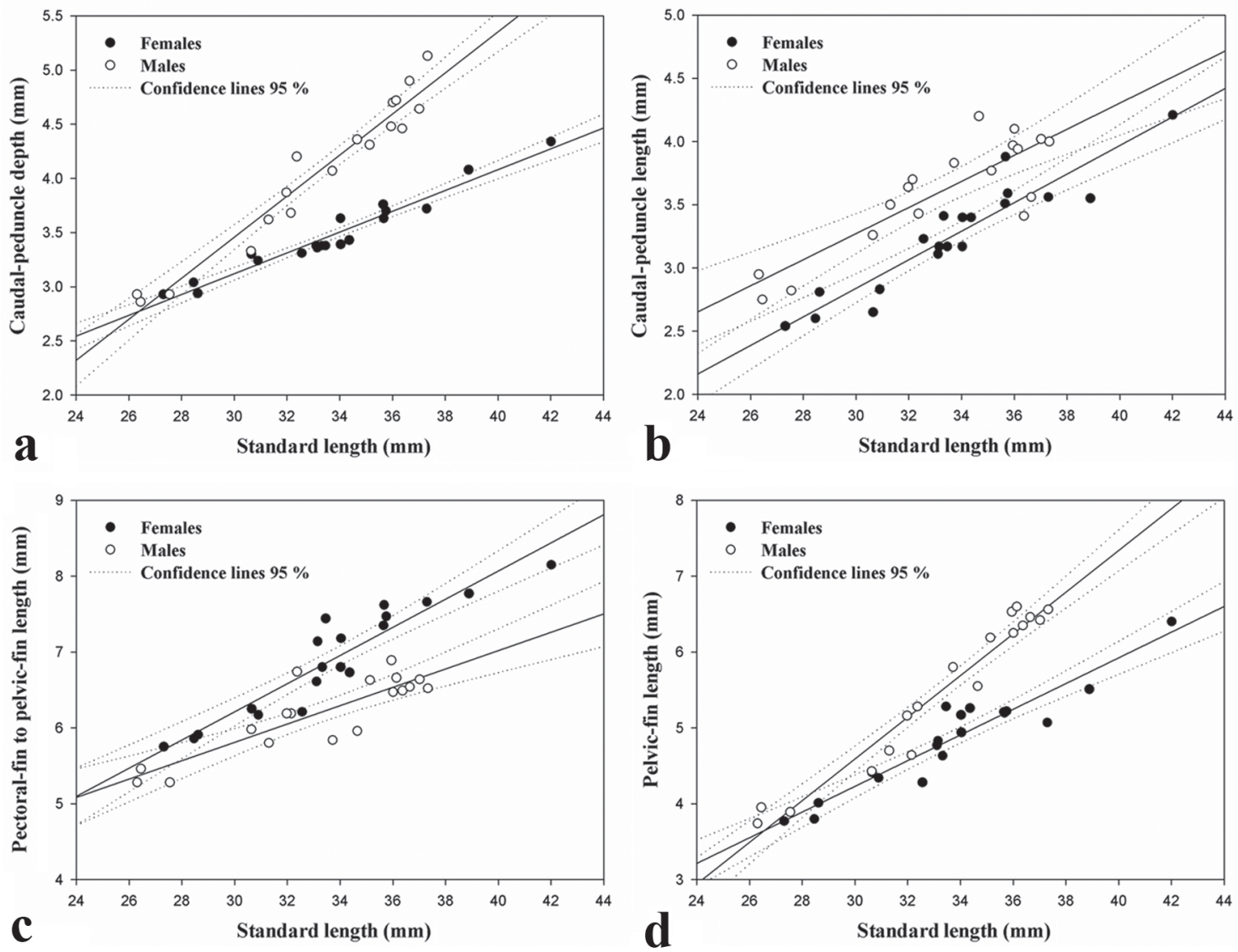

Fig. 5. Comparative regression plots of males $(\mathrm{n}=18)$ and females $(\mathrm{n}=19)$ of Gephyrocharax torresi. All variables as function of SL: (a) Caudal-peduncle depth (females: $\mathrm{r}^{2}=0.95$; males: $\mathrm{r}^{2}=0.94$ ), (b) caudal-peduncle length (females: $\mathrm{r}^{2}=0.87 ;$ males: $\mathrm{r}^{2}=0.73$ ), (c) pectoral fin to pelvic fin length (females: $\mathrm{r}^{2}=0.87$; males: $\mathrm{r}^{2}=0.74$ ), (d) pelvic-fin length (females: $\mathrm{r}^{2}=0.89$; males: $\mathrm{r}^{2}=0.94$ ).

Gephyrocharax torresi and G. melanocheir (Fig. 7) are morphologically rather similar and share, among other characters, the presence of minute hooks and the highly

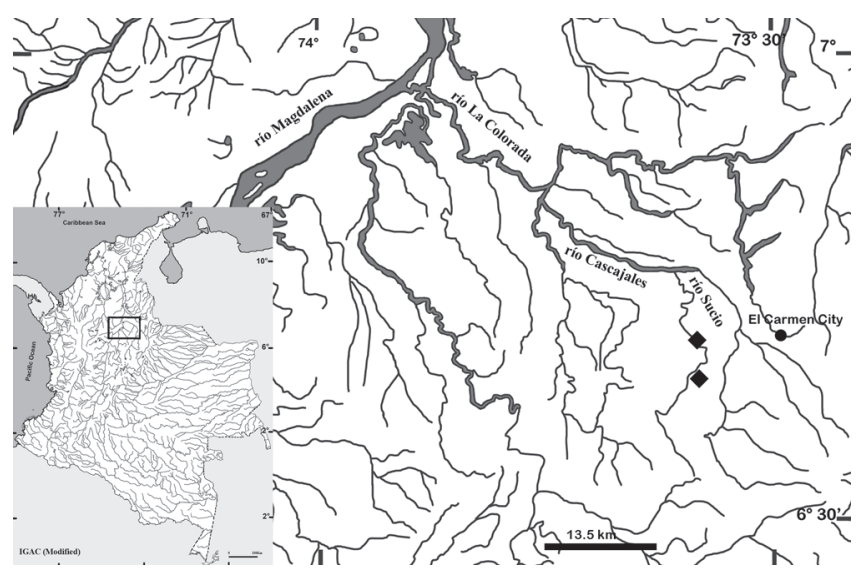

Fig. 6. Geographic distribution of Gephyrocharax torresi (black rhomboids). developed branching pattern on the distal portion of the lateral branched pectoral-fin ray in mature males (although this pattern is more complex in terms of number of branches in $G$. torresi than in G. melanocheir: $60-88$, mode $=70, \mathrm{n}=10 ; 28$ 54 , mode $=42, n=15$, respectively). Neither the remaining species of Gephyrocharax nor Corynopoma Gill and Pterobrycon Eigenmann (genera closely related to Gephyrocharax) were observed to have these features. Thus, these features shared by males of G. torresi and G. melanocheir are putative synapomorphies grouping them as sister species. A more extensive phylogenetic analysis of Gephyrocharax is necessary to test this hypothesis.

Comparative material. Corynopoma riseii: Venezuela: AI 303 (previously MBUCV 285), 3, 27.4-35.4 mm SL (2 c\&s, 27.4$34.1 \mathrm{~mm}$ SL), Carabobo, Lago Valencia basin, Finca Monte Sacro. Colombia: FMNH 56400, holotype (radiograph) of Stevardia aliata Eigenmann, 1914, $45.4 \mathrm{~mm} \mathrm{SL}$, Meta, río Negro at Villavicencio. Gephyrocharax atracaudatus: Panama: AMNH 37808, 20 of 82, 29.1-38.2 mm SL, Colón, Frijoles, Canal Zone, Quebrada Juan Grande, near Gamboa. FMNH 7573, holotype (radiograph) of Deuterodon atracaudatus Meek \& Hildebrand, 1912, 43.8 mm SL, Colón, Frijoles, Canal Zone, río Frijoles. 


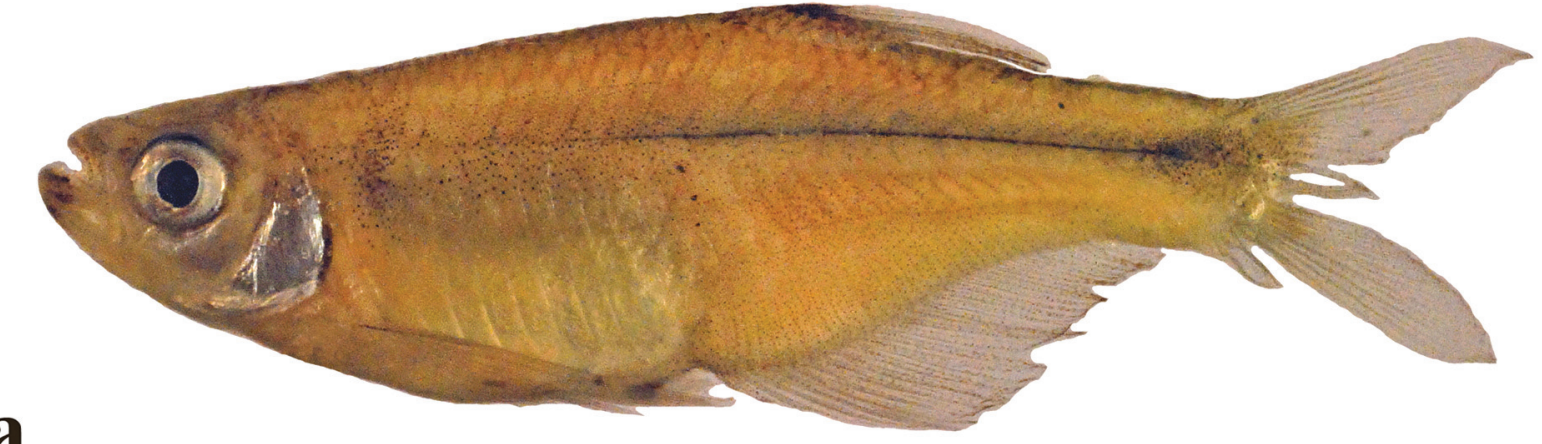

$\mathbf{a}$

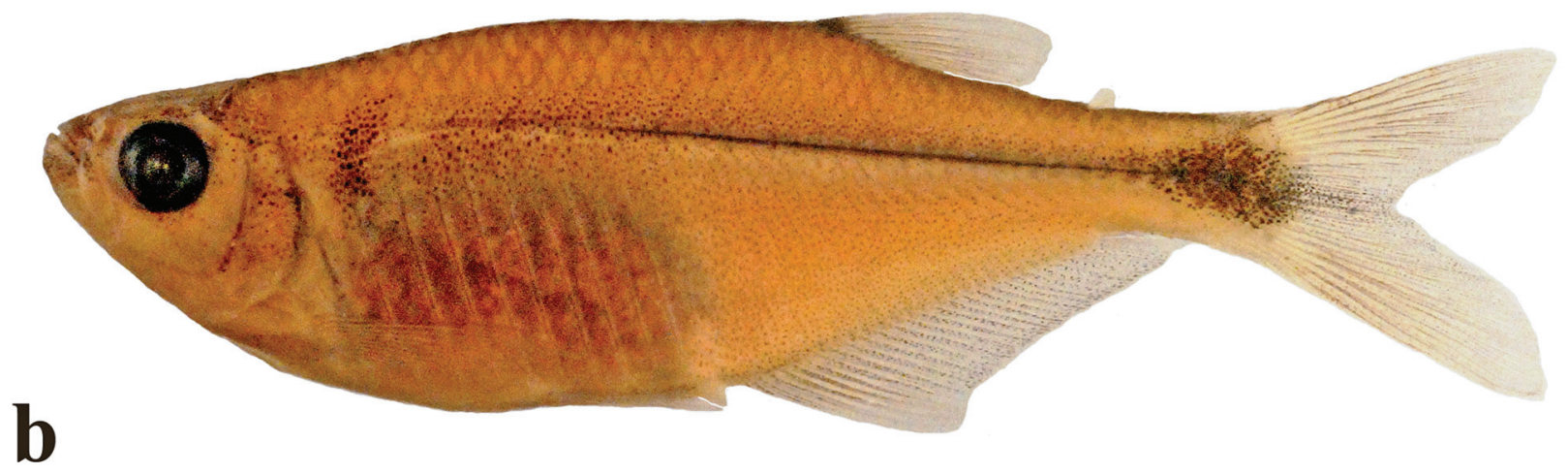

Fig. 7. Gephyrocharax melanocheir, (a) CIUA 1060, male, $32.9 \mathrm{~mm} \mathrm{SL}$, Quebrada Casanguila, río Magdalena system; (b) AI 298, female, $35.4 \mathrm{~mm}$, Quebrada Grande, río Magdalena system.

Gephyrocharax caucanus: Colombia: FMNH 56012, holotype (radiograph), $50.0 \mathrm{~mm} \mathrm{SL}$, Valle del Cauca, Cartago, upper río Cauca. MCZ 35811, 1 (radiograph), $37.5 \mathrm{~mm}$ SL, río La Paila. MCZ 35872, 1 of 2 (radiograph), $43.2 \mathrm{~mm} \mathrm{SL}$, Valle del Cauca, upper río Cauca and tributaries. USNM 81921, 3 paratypes (3 radiographs), 42.5-48.1 mm SL, Valle del Cauca, Cartago, upper río Cauca. Gephyrocharax chaparae: Bolivia: ANSP 68967, holotype (radiograph), $32.5 \mathrm{~mm}$ SL, Cochabamba, Todos Santos, río Chapare. ANSP 68968, 6 of 11 paratypes (3 radiographs), 31.0-44.7 mm SL, collected with holotype. ANPS 68979, 1 paratype, $31.0 \mathrm{~mm} \mathrm{SL}$, Cochabamba, mouth of río Chapare at its junction with río Chimore. ANSP 69195, holotype (radiograph) of Corynopomops opisthopterus Fowler, 1943, $29.8 \mathrm{~mm} \mathrm{SL}$, Cochabamba, Todos Santos, río Chapare. Gephyrocharax chocoensis: Colombia: AMNH 5330, 4 of 7, 39.6-45.1 mm SL, Chocó, Istmina, río San Juan. CAS 44278, 1 of 9 paratypes, Chocó, Istmina, río San Juan basin. FMNH 56016, holotype (radiograph), $48.6 \mathrm{~mm} \mathrm{SL}$, Chocó, Istmina,río San Juan basin. MCZ 30956, 1 of 8 (radiograph), $44.3 \mathrm{~mm} \mathrm{SL}$, Chocó, Istmina, $5^{\circ} 10^{\prime} 60^{\prime \prime N} 76^{\circ} 39^{\prime} 0^{\prime \prime} \mathrm{W}$, río San Juan basin. USNM 79208, 2 paratypes (2 radiographs), 44.7-47.8 $\mathrm{mm}$ SL, collected with holotype. Gephyrocharax intermedius: Panama: FMNH 8945, holotype (radiograph), $43.92 \mathrm{~mm} \mathrm{SL}$, río Chame. FMNH 12511, 1 paratype, $33.08 \mathrm{~mm}$ SL, collected with holotype. FMNH 12512, 1 paratype, $31.0 \mathrm{~mm} \mathrm{SL}$, collected with holotype. USNM
78556, 2 of 26 (2 radiographs), 33.4-36.5 mm SL, collected with holotype. Gephyrocharax major: CAS 44286, 9 syntypes ( 9 radiographs), 35.9-56.4 mm SL, Bolivia, Beni, río Popoi, upper río Beni basin. Gephyrocharax martae: Colombia: ZMUL 939/ 3703, holotype, 34.5 mm SL, Bolivar, Ayapel, río Batatal, tributary of San Jorge. Gephyrocharax melanocheir: Colombia: AI 298 (previously CAR 73), 6, 31.0-36.7 mm SL, Atlántico, Ponedera, Quebrada Grande, río Magdalena basin. AI 302 (previously CZUT-IC 196), 3, 35.6-37.3 mm SL (2 c\&s, 35.6$36.0 \mathrm{~mm} \mathrm{SL})$. ANSP 139153, 10 of 20, 23.6-30.5 mm SL, Magdalena, Quebrada de Aguja, $40 \mathrm{~km}$ SE of Santa Marta. CAS 44292, 1 of 6 paratypes, Tolima, Quebrada Bernal near Honda, río Magdalena basin. CAS 44293, 1 of 4 paratypes, $35.4 \mathrm{~mm} \mathrm{SL}$, Sucre, Soplaviento, town on Dique de Cartagena between Cartagena and Calamar. CIUA 250, 4 of 7, 31.2-35.0 mm SL, Caldas-Antioquia, río La Miel, río Magdalena basin. CIUA 1060, 15 of 33, 25.9-37.8 mm SL (2 c\&s, 34.3-36.7 mm SL), Caldas, Quebrada Casanguilas, tributary of río Guárino, río Magdalena basin. CZUT-IC 1878, 1, $34.3 \mathrm{~mm}$ SL, Tolima, río Alvarado, at bridge. CZUT-IC 2175, 4, 12.4-22.8 mm SL, César, río César, vereda Puente Canoa. CZUT-IC 2187, 1, 33.4 mm SL, Norte de Santander, río San Alberto, vereda Barrancabermeja. CZUT-IC 2327, 2 of 27, 39.3-41.9 mm SL, Tolima, Quebrada La Hoya, Vereda Chorrillo. FMNH 69554, 3 of 9 paratypes (3 radiographs), 32.5-39.3 mm SL, Tolima, Quebrada Bernal near 
Honda. ICNMHN 6459, Boyacá, Puerto Boyacá, Puerto Romero, Serranías Las Quinchas, Quebrada La Fieble, río Magdalena basin ICNMHN 9657, 188, 26.7-37.29 mm SL, La Guajira, Correa, Chorreras, El Cerrado, río Ranchería. IMCN 3425, 5, 23.3-29.1 mm SL, Tolima, Honda, Quebrada Bernal. IMCN 3458, 4, 34.6$36.2 \mathrm{~mm}$ SL, Tolima, Coello, río Magdalena basin, Quebrada Gualanday, Police station of Gualanday. USNM 79209, 2 paratypes (2 radiographs), 30.9-34.5 mm SL, Tolima, Quebrada Bernal. Venezuela: UF 23806, 5, 22.2-28.2 mm SL, Falcón, Zamora, El Palmar, Puente road 3. Gephyrocharax sinuensis: Colombia: ICNMHN 6843, 9, 30.7-39.6 mm SL, Córdoba, río Sinú. ICNMHN 6915, 4 of 13, 27.6-34.2 mm SL, Córdoba, río Sinú. Gephyrocharax valencia: Venezuela: ANSP 134924, 2 of 6 c\&s, 24.5-32.7 mm SL, Carabobo, Caño Cambur, tributary to Lago valencia, $11 \mathrm{~km} \mathrm{~S}$ of El Valencia. CAS 44295, 1 of 2 paratypes, $30.4 \mathrm{~mm} \mathrm{SL}$, Aragua, Maracay, río Bue. CAS 44297, holotype (radiograph), $27.7 \mathrm{~mm}$ SL, Aragua, Maracay, Lago Valencia of dock off Paper Mill. INHS 60438, 8, 28.2-39.8 mm SL, Carabobo, Lago Valencia drainage, Caño La Cumara, $3 \mathrm{~km} \mathrm{~N}$ of San Diego, $10^{\circ} 16.55^{\prime} \mathrm{N} 67^{\circ} 56.21^{\prime} \mathrm{W}$. Gephyrocharax venezuelae: Venezuela: MCZ 37269 (previously USNM 121366), 5 paratypes (5 radiographs), 29.0-33.9 mm SL, Zulia, Lago Maracaibo basin, río Negro, tributary of río Santa Ana, below mouth of río Yasa, $75 \mathrm{~km}$ by road $\mathrm{S}$ of Rosario approx. $9^{\circ} 45^{\prime} 00^{\prime \prime} \mathrm{N} 75^{\circ} 25^{\prime} 00^{\prime \prime W}$. USNM 121369, holotype (radiograph), $30.9 \mathrm{~mm}$ SL, Zulia, Lago Maracaibo basin, río San Juan at bridge south of Mene Grande, Motatán system. Gephyrocharax whaleri: Panama: FMNH 36760, 1 paratype, 48.8 mm SL, Panama, streams crossed by highway between Campana and La Venta, río de Panama. FMNH 36761, 1 paratype, 45.1 mm SL, Panama, streams crossed by highway between Campana and La Venta, río de Panama. USNM 106513, holotype (radiograph), $38.1 \mathrm{~mm}$ SL, Panama, Pacific slope, río Chame or a nearby stream. USNM 235926 (previously USNM 109276), 2 paratypes (2 radiographs), 37.17-38.80 mm SL, Panama, Pacific slope, río Chame and several smaller nearby coastal streams crossing National Highway between Campana and La Venta. Pterobrycon myrnae: Costa Rica: LACM 33861-1, 2 (c\&s) of 40 paratypes, 30.6-32.9 mm SL, Punta Arenas, Quebrada Banegas (10 m) 0.89 $\mathrm{km}$ upstream from Pacific highway 3 air km SW of Rincon.

\section{Acknowledgments}

We thank Donald Taphorn, the anonymous reviewers and the editor who improved a previous version of the manuscript; Mauricio Torres and Martha Ramírez-Pinilla (UIST) for the access to specimens used in the description of the new species. We also thank the following individuals and institutions for assistance and support: John Lundberg, Mark Sabaj Perez and Kyle Luckenbill (ANSP); Barbara Brown (AMNH); Jon Fong and Dave Catania (CAS); Carlos Ardila-Rodriguez (CAR); Luz Jiménez and Henry Agudelo (CIUA); Jaider Peña, Francisco VillaNavarro and Gladys Reinoso-Florez (CZUT-IC); Mary A. Rogers, Philip Willink, Kevin Swagel and Chris Jones (FMNH); Jose Iván Mojica, Ofelia Mejía and Gustavo Ballen (ICNMHN); Armando Ortega and Gian Carlo Sanchez (FUNINDES); Raúl Ríos, (IMCN, INCIVA); Mike Retzer and Daniel Wylie (INHS); Francisco Provenzano (MBUCV); Karsten Hartel and Andrew Williston (MCZ); Larry Page and Rob Robins (UF); Richard Vari and Sandra Raredon (USNM); and Lars Lundqvist (ZMUL). Bruno Pianzola helped with the photographs. This research was supported by Project 2814 (J.A.V-R., J.M.M. \& M.D.G.), Fundación para Promoción de la Investigación y la Tecnología, Banco de la República, Colombia. The senior author thanks the following institutions for financial support: Latin-American grant CONICET-Argentina and the Ph.D. program funding (Expte: 1000-007351/2011), Facultad de Ciencias Naturales y Museo, UNLP. This study was supported in part by the CONICET and ANPCYT (PICT 913 to M.M.A. and PICT 2008-1201 to J.M.M.).

\section{Literature Cited}

Bonilla-Rivero, A. \& H. López-Rojas. 2001. Diferenciación morfológica cuantitativa de las especies del género Gephyrocharax Eigenmann 1912 (Pisces: Characidae: Glandulocaudinae) de Venezuela. Acta Biológica Venezuélica, 21: 1-10.

Dahl, G. 1943. New or rare fishes of the family Characinidae from the Magdalena system. Kungliga Fysiografiska Sällskapets i Lund Förhandlingar, 12: 215-220.

Dahl, G. 1971. Los Peces del Norte de Colombia. Instituto de Desarrollo de los Recursos Naturales Renovables, Inderena, Bogotá D. C..

Dahl, G. \& F. Medem. 1964. Informe sobre la fauna acuática del Río Sinú. Corporación Autónoma regional de los Valles del Magdalena y del Sinú, CVM. Departamento de Investigaciones Ictiológicas y Faunísticas, Bogotá D. C.

Eigenmann, C. H. 1912. Some results from an ichthyological reconnaissance of Colombia, South America. Part I. Indiana University Studies, 8: 1-27.

Eigenmann, C. H. \& G. S. Myers. 1929. The American Characidae. Part 5. Memoirs of the Museum of Comparative Zoölogy, 43: 429-558.

Fink, W. L. \& S. H. Weitzman. 1974. The so-called cheirodontin fishes of Central America with descriptions of two new species (Pisces: Characidae). Smithsonian Contributions to Zoology, 172: $1-46$.

Hammer, Ø., D. A. T. Harper \& P. D. Ryan. 2001. PAST: Paleontological Statistics Software Package for Education and Data Analysis. Palaeontologia Electronica, 4: 1-9. Available from: http://palaeo-electronica.org/2001_1/past/issue1_01.htm

Menezes, N. A. \& S. H. Weitzman. 2009. Systematics of the Neotropical fish subfamily Glandulocaudinae (Teleostei: Characiformes: Characidae). Neotropical Ichthyology, 7: 295370.

Miles, C. 1947. Los peces del río Magdalena. Ministerio de la Economía Nacional, Sección de Piscicultura, Pesca y Caza. Edition El Grafico, Bogotá D. C.

Mirande, J. M. 2010. Phylogeny of the family Characidae (Teleostei: Characiformes): from characters to taxonomy. Neotropical Ichthyology, 8: 385-568.

Schultz, L. P. 1944. The fishes of the family Characinidae from Venezuela, with descriptions of seventeen new forms. Proceeding of the United States National Museum, 95: 235-367.

Taphorn, D. C. \& C. G. Lilyestrom. 1984. Clave para los peces de agua dulce de Venezuela. Revista Unellez de Ciencia y Tecnología, 2: 5-30. 
Taylor, W. R. \& G. C. van Dyke. 1985. Revised procedures for staining and clearing small fishes and other vertebrates for bone and cartilage study. Cybium, 9: 107-119.

Weitzman, S. H. 2003. Subfamily Glandulocaudinae (Characins, tetras). Pp. 222-230. In: Reis, R. E., S. O. Kullander \& C. J. Ferraris Jr. (Eds.). Check List of the Freshwater Fishes of South and Central America. Porto Alegre, Edipucrs.

Weitzman, S. H. \& N. A. Menezes. 1998. Relationships of the tribes and genera of the Glandulocaudinae (Ostariophysi: Characiformes: Characidae) with a description of a new genus, Chrysobrycon. Pp. 171-192. In: Malabarba, L. R., R. E. Reis, R. P. Vari, Z. M. S. Lucena \& C. A. S. Lucena (Eds.). Phylogeny and Classification of Neotropical Fishes. Porto Alegre, Edipucrs.

Submitted September 27, 2012

Accepted May 2, 2013 by Fabio Di Dario

Published June 28, 2013 